\title{
Influence of time of day the milk and season on the somatic cell count under Hungarian conditions
}

\begin{abstract}
Summary
This research indicates that the numerical value of the emptying of somatic cells as a result of the effect of time of day cannot be demonstrated and interval difference less than 2 hours between milking does not significantly influence the formation of somatic cells and their absolute quantity.

Moreover it was confirmed that subclinical mastitis also occurs in individual udder quarters of healthy qualified cows producing bulk milk with somatic cell count below 400 thousand / ml. Udder quarter with mastitis was found in $15,2 \%$ of cows of the tested stock realising this production, which can be considered a significant proportion and is a justification for eliminating and taking udder health care of these animals.
\end{abstract}

Key Words: somatic cell, milk, time of day, season, mastitis

\section{Zusammenfassung}

Titel der Arbeit: Einfluss von Melkzeit und Jahreszeit auf den Gehalt somatischer Zellen in der Milch unter ungarischen Bedingungen

Bei 303 Kühen eines Betriebes mit unterschiedlichem H.-F.-Anteil wurde der Einfluss der täglichen Melkzeit sowie der Jahreszeit auf den Gehalt somatischer Zellen in der Milch untersucht. Es konnte nachgewiesen werden, dass Differenzen des Melkintervalls von weniger als zwei Stunden nur einen unbedeutenden Einfluss auf den Zellgehalt hatten. Auch bei Kühen mit einer somatischen Zellzahl von weniger als 400000/ml fand sich in einzelnen Eutervierteln subklinische Mastitis. Der relativ hohe Anteil von 15,2 \% an Tieren dieser Herde, bei denen Mastitis nachgewiesen werden konnte, rechtfertigt die Merzung dieser Tiere und erfordert weitere Maßnahmen der Gesundheitsfürsorge.

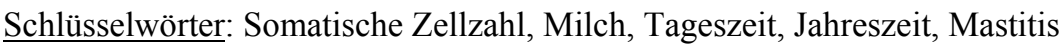

\section{Introduction}

One of the diseases causing the highest economic loss on dairy farms is bovine mastitis that may lead to reduced milk production as well as fat, casein and, to a lesser extent lactose content. Simultaneously with other inflammation markers - certain serum proteins such as albumin, $\alpha 1$-antitripsine or ions - sodium or chloride ions e.g. - as well as the increased activity of certain enzymes such as N-acyl-glucoseaminidase - leukocytes (the so called somatic cells) accumulate in the milk from the blood (BEDÖ et al., 1996; SZÜCS, 1998; ALBERT and HUSZENICZA, 2000; DOHY, 2001). The dairy industry uses somatic cell count (SCC) as a special parameter of raw milk making it essential to pay constant attention to keeping somatic cells numbers in the milk at a low value in order to comply with set quality standards. The somatic cell counts of milk influenced by many factors. Genetic analyses demonstrate the large genetic variability in SCC (DISTL, 2001). All estimates mainly were in the range of $\mathrm{h}^{2}=1$ to $4 \%$. (AMIN, 2000; AMIN et al., 2000; DISTL, 2001; IMBAYARWO-CHIKOSI et al., 2001). Therefore many authors demand and many 
countries practice the inclusion of SCC in the selection system (SOELKNER et al., 2000; AMIN et al., 2000; DISTL, 2000; AMIN, 2001). There are also relations between milk yield and number of lactation to SCC (SIMIANER et al., 1991; BEDO et al., 1996; NAUMANN et al., 1998; AMIN et al., 2000; IMBAYARWO-CHIKOSI et al., 2001; AMIN, 2001). NAUMANN et al. reported significant influence of the lactation stadium. Cows with very long duration of decline had the highest SCC of milk. Some authors observed that there is also a close correlation between uddermorphologic traits and the values of SCC (NAUMANN and FAHR, 2000; GULYAS and IVANCSICS, 2001; WUFKA and WILLEKE, 2001).

As the available literature has not provided definite proof to the effect of the time of day I tested this effect for the purpose of decreasing the milk somatic cell count.

Several authors have tested the effect of the time of day made on somatic cell count (SMITH and SHULTZE, 1967; SYRSTAD and RON, 1978; GALDVIN et al., 1991; FUENTE et al., 1997), however in the case of milk samples taken in different times of day the change of milk somatic cell count is attributable rather to the variability of time between milking, than to the effect of the actual time of day.

Therefore the aim of the test was to definitely clear the effect of the time of day on somatic cell count, and the development of its absolute change in number.

\section{Materials and Methods}

Tested stock

The test were made on a Central-Hungarian cattle farm in three repetitions (February, May, July-August) including 303 cows in the middle period of their lactation, housed in the same stall. Black and White Holstein Friesian cows with different Holstein blood percentage formed the tested stock. Cows were kept in a loose stall with deep straw bedding. Twice a day milking was carried out in a milking barn with Alfa Laval milking machine of herringbone system. According to the Hungarian practice, feed was based on maize silage, alfalfa and grass hay, completed with concentrate depending on the production.

Test of the time of day

To establish the effect of the part of day were made measurements in three different seasons (winter, spring and summer), in months characteristic of the season and at the morning and evening milking in accordance with the technology, as shown in Table 1.

Table 1

Sampling days and time

\begin{tabular}{|c|c|c|c|c|c|c|}
\hline \multirow{2}{*}{$\begin{array}{l}\text { Sampling month } \\
\text { Sampling time }\end{array}$} & \multicolumn{2}{|c|}{ February } & \multicolumn{2}{|c|}{ May } & \multicolumn{2}{|c|}{ July-August } \\
\hline & $\begin{array}{l}\text { Morning } \\
4^{30}\end{array}$ & $\begin{array}{c}\text { Afternoon } \\
15^{30}\end{array}$ & $\begin{array}{l}\text { Morning } \\
4^{30}\end{array}$ & $\begin{array}{c}\text { Afternoon } \\
15^{30}\end{array}$ & $\begin{array}{c}\text { Morning } \\
4^{30}\end{array}$ & $\begin{array}{c}\text { Afternoon } \\
15^{30}\end{array}$ \\
\hline & \multicolumn{2}{|c|}{$02 / 02 / 2000$} & \multicolumn{2}{|c|}{$08 / 05 / 2000$} & \multicolumn{2}{|c|}{$25 / 07 / 2000$} \\
\hline & \multicolumn{2}{|c|}{$09 / 02 / 2000$} & \multicolumn{2}{|c|}{$11 / 05 / 2000$} & \multicolumn{2}{|c|}{$01 / 08 / 2000$} \\
\hline & \multicolumn{2}{|c|}{$16 / 02 / 2000$} & \multicolumn{2}{|c|}{$18 / 05 / 2000$} & \multicolumn{2}{|c|}{$10 / 08 / 2000$} \\
\hline & \multirow{2}{*}{\multicolumn{2}{|c|}{$23 / 12 / 2000$}} & \multirow{2}{*}{\multicolumn{2}{|c|}{$23 / 05 / 2000$}} & \multirow{2}{*}{\multicolumn{2}{|c|}{$\begin{array}{l}15 / 08 / 2000 \\
22 / 08 / 2000\end{array}$}} \\
\hline & & & & & & \\
\hline
\end{tabular}

Measurements were made four days in February and May, and five in July-August. Number of cows included in the test was 116 in February, 94 in May and 93 in July- 
August. In the course of each test, the quantity of freshly produced milk, as well as protein, fat and lactose content and rate and the somatic cell count of the given sample were determined according to the milk recording rules in the Gödöllö milk laboratory of the Hungarian milk recording organisation (Livestock Performance Testing Ltd.) (KATONA, 1991; LEJTÉNYI and MÉSZÁROS, 1998).

Based on the previous findings of VÁGI (1998), somatic cell count data obtained from milk sample tests do not show normal distribution and their variance also proved to be unstable, consequently they are not suitable for processing of biometrics. For the elimination of this, I used somatic cell scores obtainable through the logarithm transformation of somatic cell count of milk samples which - as opposed to the somatic cells - already present a normal distribution. In addition to the somatic cell count and somatic cell scores I also applied a new somatic cell count transformational method, that is the so called 'total somatic cell count number' (Tot SCC), as well as its logarithmic form (Tot log SCC) for the purpose of comparing the total somatic cell count number in the milk produced by the tested animals:

Tot SCC and Tot log SCC were calculated by means of the following formula:

$\left(\mathrm{SCC} \times\right.$ milk kg) $\times 10^{3}$ as well as $10 \log (\mathrm{SCC} \times$ milk $\mathrm{kg}) \times 10^{3}$

Data were processed by the General Linear Model - Repeated Measures method according to the formula as follows:

$$
\mathrm{y}_{\mathrm{ijklm}}=\mu+\mathrm{N}_{\mathrm{i}}+\mathrm{Sz}_{\mathrm{j}}+\mathrm{P}_{\mathrm{k}}+\mathrm{M}_{\mathrm{l}}+\mathrm{V}_{\mathrm{m}}+\mathrm{e}_{\mathrm{ijklm}}
$$

$\mathrm{N}_{\mathrm{j}}=$ effect of sampling day (days $\left.1,2,3,4,5\right) ; \mathrm{Sz}_{\mathrm{k}}=$ effect of milking time (morning and evening); $\mathrm{L}_{\mathrm{k}}=$ effect of lactation $(2,3,4) ; \mathrm{M}_{1}=$ effect of the result of Californian Mastitis Test ( 1 positive, 2 negative); $\mathrm{V}_{\mathrm{m}}=$ random effect of cows; $\mathrm{e}_{\mathrm{ijklm}}=$ residue effect.

Dependent variables (Y) were as follows: milk quantity, rate of fat, protein and sugar, SCC, Log SCC, Tot SCC and Tot log SCC.

\section{California Mastitis Test}

California Mastitis Test (CMT) was done on the milk collected from individual udder quarters with the Mastitest ${ }^{\mathrm{R}}$ (Phylaxia-Sanofi Co.) reagent following the recommendations of the manufacturer, and somatic cell counts of composite milk samples were also counted. Milk samples with barely visible, ' + ' results were considered negative in order to eliminate false positive samples and to increase the pathognomic value of tests considered positive. Determination of total cell counts was carried out in the milk laboratory of the Livestock Performance Testing Ltd., Gödöllö on a Fossomatic fluoro-optical instrument. Data gained during the tests were statistically evaluated with tables of frequencies of the SPSS 9.0 software.

\section{Results and Discussion}

Data entered on certain sampling days and their laboratory evaluation are shown in Tables 2, 3, and 4 where I also include the decimal logarithmic forms (Log SCC) of the calculated somatic cell count, the total somatic cell count number (Tot SCC), the 
decimal logarithmic value of the total somatic cell count number (Tot log SCC), as well as the statistical reliability of the obtained values.

Table 2

Least-squares means and significance of main effects (type III P $>$ F) of milking test variables in February

\begin{tabular}{|c|c|c|c|c|c|c|c|c|c|c|}
\hline \multirow{3}{*}{$\begin{array}{l}\text { Dependant variable } \\
\text { February }(n=116)\end{array}$} & \multicolumn{8}{|c|}{ Sampling day } & \multicolumn{2}{|c|}{ Milking time } \\
\hline & \multicolumn{2}{|c|}{1} & \multicolumn{2}{|r|}{2} & \multicolumn{2}{|c|}{3} & \multicolumn{2}{|c|}{4} & \multirow[b]{2}{*}{ A.M. } & \multirow[b]{2}{*}{ P.M. } \\
\hline & a.m. & p.m. & a.m. & p.m. & a.m. & p.m. & a.m. & p.m. & & \\
\hline Milk yield (kg) & 14.05 & 11.64 & 14.84 & 11.59 & 13.61 & 11.93 & 13.84 & 11.19 & 14.10 & 11.61 \\
\hline Fat $(\%)$ & 3.64 & 4.48 & 3.51 & 4.41 & 3.57 & 3.94 & 3.77 & 4.30 & 3.63 & 4.28 \\
\hline Protein $(\%)$ & 3.09 & 3.11 & 3.02 & 3.05 & 3.05 & 3.19 & 3.10 & 3.03 & 3.06 & 3.10 \\
\hline Lactose $(\%)$ & 4.93 & 4.90 & 4.86 & 4.85 & 4.87 & 4.93 & 4.84 & 4.81 & 4.88 & 4.88 \\
\hline $\operatorname{SCC} 10^{3}$ & 334 & 446 & 377 & 477 & 431 & 559 & 369 & 405 & 382 & 468 \\
\hline $\log$ SCC & 2.09 & 2.26 & 2.04 & 2.24 & 2.12 & 2.26 & 2.11 & 2.20 & 2.20 & 2.37 \\
\hline Tot SCC $\left(\times 10^{3}\right)$ & 4739 & 5280 & 5512 & 5397 & 5884 & 6477 & 5034 & 4334 & 5292 & 5372 \\
\hline Tot log SCC & 9.22 & 9.32 & 9.20 & 9.29 & 9.25 & 9.33 & 9.24 & 9.24 & 9.35 & 9.43 \\
\hline \multirow[t]{2}{*}{ February } & \multicolumn{10}{|c|}{ Significance of main effects type IIIP $>F$} \\
\hline & \multicolumn{2}{|c|}{ Day } & \multicolumn{3}{|c|}{ Milking time } & \multicolumn{3}{|c|}{ Parity } & \multicolumn{2}{|c|}{ CMT } \\
\hline Milk yield (kg) & \multicolumn{2}{|r|}{ NS } & \multicolumn{3}{|c|}{$* * *$} & \multicolumn{3}{|c|}{ NS } & \multicolumn{2}{|c|}{ NS } \\
\hline Fat $(\%)$ & \multicolumn{2}{|r|}{$*$} & \multicolumn{3}{|c|}{$* * *$} & \multicolumn{3}{|c|}{ NS } & \multicolumn{2}{|c|}{ NS } \\
\hline Protein $(\%)$ & \multicolumn{2}{|r|}{ NS } & \multicolumn{3}{|c|}{ NS } & \multicolumn{3}{|c|}{ NS } & \multicolumn{2}{|c|}{ NS } \\
\hline Lactose $(\%)$ & \multicolumn{2}{|r|}{ NS } & \multicolumn{3}{|c|}{ NS } & \multicolumn{3}{|c|}{ NS } & \multicolumn{2}{|c|}{$* *$} \\
\hline $\operatorname{SCC} 10^{3}$ & \multicolumn{2}{|r|}{ NS } & \multicolumn{3}{|c|}{ NS } & & NS & & $* *$ & \\
\hline Log SCC & & NS & & $* * *$ & & & NS & & $* *$ & \\
\hline Tot SCC $\left(\times 10^{3}\right)$ & & NS & & NS & & & $*$ & & $* *$ & \\
\hline Tot $\log \mathrm{SCC}$ & & NS & & $*$ & & & NS & & $* *$ & \\
\hline
\end{tabular}

$* \mathrm{P}<0,05, * * \mathrm{P}<0,01, * * * \mathrm{P}<0,001$

Table 3

Least-squares means and significance of main effects (type III P $>$ F) of milking test variables in May

\begin{tabular}{|c|c|c|c|c|c|c|c|c|c|c|}
\hline \multirow{3}{*}{$\begin{array}{l}\text { Dependant variable } \\
\text { May }(n=94)\end{array}$} & \multicolumn{8}{|c|}{ Sampling day } & \multicolumn{2}{|c|}{ Milking time } \\
\hline & \multicolumn{2}{|c|}{1} & \multicolumn{2}{|r|}{2} & \multicolumn{2}{|c|}{3} & \multicolumn{2}{|c|}{4} & \multirow[b]{2}{*}{ A.M. } & \multirow[b]{2}{*}{ P.M. } \\
\hline & a.m. & p.m. & a.m. & p.m. & a.m. & p.m. & a.m. & p.m. & & \\
\hline Milk yield (kg) & 15.11 & 12.61 & 14.64 & 12.80 & 15.37 & 13.12 & 15.17 & 12.39 & 15.07 & 12.73 \\
\hline Fat $(\%)$ & 3.60 & 4.09 & 3.71 & 3.98 & 3.13 & 4.01 & 3.65 & 4.14 & 3.51 & 4.05 \\
\hline Protein (\%) & 3.03 & 2.99 & 3.03 & 2.98 & 3.01 & 2.95 & 3.03 & 3.05 & 3.03 & 2.99 \\
\hline Lactose $(\%)$ & 4.84 & 4.82 & 4.90 & 4.89 & 4.89 & 4.84 & 4.86 & 4.89 & 4.87 & 4.86 \\
\hline $\operatorname{SCC} 10^{3}$ & 456 & 553 & 500 & 498 & 543 & 529 & 412 & 489 & 478 & 520 \\
\hline $\log \mathrm{SCC}$ & 2.16 & 2.24 & 2.16 & 2.20 & 2.22 & 2.25 & 2.13 & 2.28 & 2.17 & 2.24 \\
\hline Tot SCC $\left(\times 10^{3}\right)$ & 6848 & 6575 & 7710 & 6076 & 8433 & 7259 & 6415 & 6235 & 7381 & 6566 \\
\hline Tot $\log$ SCC & 9.33 & 9.33 & 9.32 & 9.30 & 9.40 & 9.36 & 9.30 & 9.36 & 9.46 & 9.45 \\
\hline \multirow[t]{2}{*}{ May } & \multicolumn{10}{|c|}{ Significance of main effects type IIIP $>$ F } \\
\hline & \multicolumn{2}{|c|}{ Day } & \multicolumn{3}{|c|}{ Milking time } & \multicolumn{3}{|c|}{ Parity } & \multicolumn{2}{|c|}{ CMT } \\
\hline Milk yield (kg) & \multicolumn{2}{|c|}{ NS } & \multicolumn{3}{|c|}{$* * *$} & \multicolumn{3}{|c|}{ NS } & \multicolumn{2}{|c|}{ NS } \\
\hline Fat $(\%)$ & \multicolumn{2}{|r|}{ NS } & \multicolumn{3}{|c|}{$* * *$} & \multicolumn{3}{|c|}{ NS } & \multicolumn{2}{|c|}{ NS } \\
\hline Protein $(\%)$ & \multicolumn{2}{|r|}{ NS } & \multicolumn{3}{|c|}{$*$} & \multicolumn{3}{|c|}{ NS } & \multicolumn{2}{|c|}{ NS } \\
\hline Lactose $(\%)$ & \multicolumn{2}{|r|}{ NS } & \multicolumn{3}{|c|}{ NS } & \multicolumn{3}{|c|}{ NS } & \multicolumn{2}{|c|}{ NS } \\
\hline $\operatorname{SCC} 10^{3}$ & \multicolumn{2}{|r|}{ NS } & \multicolumn{3}{|c|}{ NS } & & NS & & $* * *$ & \\
\hline Log SCC & & NS & & NS & & & NS & & $* * *$ & \\
\hline Tot SCC $\left(\times 10^{3}\right)$ & & NS & & NS & & & NS & & $* * *$ & \\
\hline Tot $\log$ SCC & & NS & & NS & & & NS & & $* * *$ & \\
\hline
\end{tabular}

Tables 2, 3, and 4 illustrate, that the quantity of milk from the morning milking was always characteristically higher than from the evening one. 
Table 4

Least-squares means and significance of main effects (type III P $>$ F) of milking test variables in July-August

\begin{tabular}{lcccccccccccc}
\hline Dependant variable & \multicolumn{1}{c}{} & \multicolumn{1}{c}{ 1 } & \multicolumn{4}{c}{2} & \multicolumn{3}{c}{3} & \multicolumn{4}{c}{4} & \multicolumn{4}{c}{ Milking time } \\
\hline July-August (n=93) & a.m. & p.m. & a.m. & p.m. & a.m. & p.m. & a.m. & p.m. & a.m. & p.m. & A.M. & P.M. \\
\hline Milk yield (kg) & 15.99 & 13.46 & 14.81 & 12.54 & 14.67 & 12.49 & 13.72 & 11.36 & 12.33 & 10.42 & 14.40 & 12.11 \\
Fat (\%) & 3.67 & 3.79 & 3.60 & 4.13 & 3.42 & 3.36 & 3.79 & 4.04 & 3.90 & 4.00 & 3.66 & 3.83 \\
Protein (\%) & 3.07 & 3.04 & 3.10 & 3.06 & 3.03 & 3.03 & 3.03 & 3.00 & 2.89 & 2.85 & 3.03 & 3.01 \\
Lactose (\%) & 4.96 & 4.93 & 4.82 & 4.82 & 4.91 & 4.86 & 4.89 & 4.87 & 4.81 & 4.80 & 4.88 & 4.86 \\
SCC 10 & 314 & 337 & 391 & 452 & 369 & 442 & 306 & 365 & 399 & 553 & 348 & 402 \\
Log SCC & 2.11 & 2.19 & 2.22 & 2.28 & 2.25 & 2.30 & 2.20 & 2.28 & 2.25 & 2.34 & 2.19 & 2.26 \\
Tot SCC (x10 $\left.{ }^{3}\right)$ & 4850 & 4288 & 5673 & 5709 & 5336 & 5164 & 4091 & 3976 & 4748 & 5661 & 4979 & 4996 \\
Tot log SCC & 9.30 & 9.30 & 9.37 & 9.36 & 9.40 & 9.38 & 9.32 & 9.31 & 9.32 & 9.34 & 9.45 & 9.44 \\
\hline
\end{tabular}

\begin{tabular}{lcccc}
\hline July-August & \multicolumn{4}{c}{ Significance of main effects type IIIP $>\mathrm{F}$} \\
\hline & Day & Milking time & Parity & CMT \\
\hline Milk yield (kg) & $* * *$ & $* * *$ & NS & NS \\
Fat (\%) & $* * *$ & $*$ & NS & NS \\
Protein (\%) & $* * *$ & $*$ & NS & NS \\
Lactose (\%) & $* * *$ & $*$ & NS & $* *$ \\
SCC $10^{3}$ & NS & NS & NS & $* * *$ \\
Log SCC & $*$ & $*$ & NS & $* * *$ \\
Tot SCC $\left(x 10^{3}\right)$ & NS & NS & NS & $* * *$ \\
Tot $\log$ SCC & NS & NS & NS & $* * *$ \\
\hline${ }^{*} P<0,05, * *$ P $<0,01, * * P<0,001$ & & & &
\end{tabular}

$* \mathrm{P}<0,05,{ }^{* *} \mathrm{P}<0,01,{ }^{* * * \mathrm{P}<0,001}$

The averaged monthly quantity of milk obtained from the morning milking exceeded that of from the evening milking by $18 \%$ in February, $16 \%$ in May and $16 \%$ in JulyAugust.

This data agrees with the literature, indicating a higher somatic cell count in the evening samples. The somatic cell count in the evening samples was $+18 \%$ higher $(\mathrm{P}<0,001)$ in February, $8 \%$ in May (not significantly) and $13 \%(\mathrm{P}<0,05)$ in JulyAugust.

However it is noteworthy that, in accordance with the dairy technology included in the test, 13 hours passed prior to the morning milking, while it was 11 hours in the case of the evening milking.

Thus the obtained results confirms earlier research that increase of somatic cell count may be correlated with the time between milking.

However if in addition to the change of somatic cell count, we consider the development of the actual number of somatic cells, another explanation emerges.

From tables 2, 3, and 4 total amount of somatic cells (Tot SCC) shows little variation between morning and evening milkings.

Based on the samples taken in the afternoon in February, there was $\log _{10} 0,08(+0,84$ $\%)$ increase in the somatic cell count $(\mathrm{P}<0,05)$ while total somatic cell count tested in the May and July-August samples were only $\log _{10} 0,01(+0,1 \%)$ in the evening milk.

Although the results confirm that the somatic cell count - similarly to the fat and protein content - shows a close correlation with the quantity of produced milk the practically continuous emptying of somatic cells is not significantly influenced by shorter time intervals between milking, that in this case is 2 hours.

In the course of testing the effect of the time of day made on the somatic cell count, I executed the semiquantitative determination of somatic cell count as collateral test, 
known as California Mastitis Test (CMT), or Schalm Mastitis Test in the technical literature. Its major advantage is that it is readily available as an in situ test in the stall and also provides a chance to differentiate between different udder quarters.

Based on experimental data where milk somatic cell numbers of individual udder quarters were identified simulataneously by quantitative and semi-quantitative tests and data were compared consecutively, the CMT showed high sensitivity and specificity and the results gave high correlation values $(r=0.6$ to 0.8$)$ with those gained by quantitative tests (GALTON et al., 1979; OKELLO-UMA and GIBSON, 1979; BATRA and MCALLISTER, 1984; PEDNEKAR et al., 1992; FANDREJEWSKA, 1993; BRITO et al., 1997).

The principle of the test lays in the phenomenon that nuclear material of leucocytes forms a slimy precipitate in the presence of a surface active detergent (Na lauryl sulphate) and formation of the precipitate is directly proportional to the number of cells in the milk (MILNE, 1977; MILNE and LANGEN, 1977).

The purpose of this study was to identify, whether udder quarters with mastitis in what proportion can be found in healthy qualified animals with bulk milk below 400 thousand $\mathrm{ml} \mathrm{SCC}$, kept in an average Hungarian dairy.

Data are summarised in Table 5. The total number of cows, number '++' positive by CMT and number of positive quarters are also given according to months of milk sampling and to different SSC values.

Cows with SSC below 400 thousand per ml composite milk were used for evaluation. Cows were divided into two groups depending on whether their SCC values were below or above 100 thousand cells per $\mathrm{ml}$.

Table 5

Number of California Mastitis Test (CMT) positive cows and udderquarters in the groups

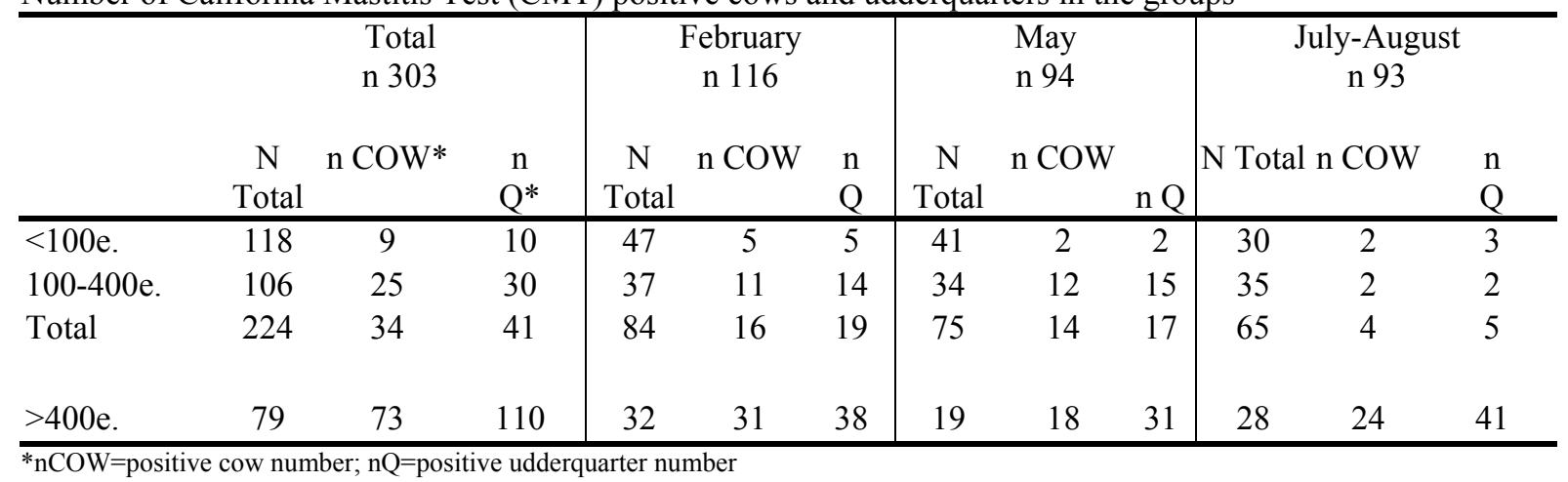

Of the 118 cows with SCC below 100 thousand per ml composite milk, a total of 10 udder quarters of 9 cows gave ' ++ ' or higher result by CMT. These nine cows with subclinical mastitis represent $7.63 \%$ of the whole group.

In the SSC category of 100 to 400 thousand cells per ml a total of 106 cows were tested, with 30 udder quarters of 25 animals producing milk with positive results by the set criteria. These 25 cows with subclinical mastitis represent $23.58 \%$ of the whole group.

When all animals with SCC values below 400 thousand per $\mathrm{ml}$ were evaluated together, 41 quarters of 34 animals tested positive, representing $15.18 \%$ of the 224 tested animals. 
The results indicate that cows with somatic cell numbers below 400 thousands per $\mathrm{ml}$ may still suffer from sub-clinical mastitis in at least one of their udder quarters.

As expected, the ratio of positive cows was lower (only $7.63 \%$ ) in the group of less than 100 thousand cells per $\mathrm{ml}$, while in the group of 100-400 thousand cells per $\mathrm{ml}$ almost one quarter of the animals suffered from mastitis.

In this research, the CMT was a supplementary study, therefore it was not designed to examine the ethiology of the sub-clinical mastitis cases. Therefore no data are available on the prevalence of contagious agents such as Staphylococcus aureus amongst the otherwise considerably high number of cows with sub-clinical mastitis, but tested as healthy in the routine udder health work.

The experiments indicate that within a planned and comprehensive udder health investigation it is necessary to screen all udder quarters of all milking cows at regular intervals.

The most cost effective method is to use inexpensive and simple infection marker tests (e.g. SCC) to screen udder quarters for mastitis and to identify pathogens of the positive udder quarters consecutively with more comprehensive bacteriological tests.

With this method - when appropriate bacteriological diagnostics are available - udder quarters/cows shedding contagious bacteria can be identified reliably, along with other agents present in the herd, preventing considerable economical loss. Thus, a specific regime can be implemented to reduce or treat mastitis.

\section{Acknowledgements}

The author gratefully thank Szent István University, Gödöllö, Hungarian Livestock Performance Testing Ltd. (Gödöllö), National Agricultural Quality Control Institute, Central Veterinary Institute and Arany Tej Ltd. for their cooperation.

\section{References}

ALBERT, M.; HUSZENICZA, GY.:

The clinical and pathology characteristic of mastitis. In: SIMON, F., SZITA, G., MERÉNYI, I. (ed.): Udder health and cow milk quality. Mezőgazda Kiadó, Budapest, 2000, 172-186 AMIN, A.A. :

Lactation and Sample Test-Day Multi-trait animal model for genetic evaluation of somatic cell scores in Hungarian Holstein Friesian crossbreeds. Arch. Tierz., Dummerstorf 44 (2001) 3, 263-275

AMIN, A.A.; GERE, T.; KISHK, W.H.:

Additive genetic variance and covariance in some reproductive disorders in Hungarian Holstein Friesian using multi-trait animal model. Arch. Tierz., Dummerstorf 43 (2000) 6, 573-581

BATRA, T.R. ; MCALLISTER, A.J.:

A comparison of mastitis detection methods in dairy cattle. Can. J. Anim. Sci. 64 (1984), 305-312

BEDÖ, S.; GUNDEL, J.-né, SZÉKELY, Zs.:

Variation in milk composition and somatic cell count of Holstein-Friesian cows of different parity. Állattenyésztés és Takarmányozás (Animal Breeding and Feeding). 45. 5. (1996), 503-513

BRITO, J.R.F.; CALDEIRA, G.A.V.; VERNEQUE, R.S.; BRITO, M.A.V.P.:

Sensitivity and specificity of the California Mastitis Test compared to somatic cell count for the

DISTL, O. diagnosis of mastitis. Pesq. Vet. Brasil. 1 (1997), 49-53

Die Bedeutung von Gesundheitsmerkmalen in der Zucht von Milchrindern. Arch. Tierz., Dummerstorf 44 (2001) 4, 365-380

DOHY, J.: 
Resistance breeding against mastitis. Present situation and future of the Hungarian dairy. Scientific Conference at the HAS, Budapest, 2001 October 25. In: Állattenyésztés és Takarmányozás (Animal Breeding and Feeding). 50. 5. 398-402.p. 2001

FANDREJEWSKA, M.:

Somatic cell count in quarter foremilk of cows from small herds with a high level of subclinical mastitis. J. Anim. Feed Sci. 2 (1993), 15-26

FUENTE, L.F.; PRIMITIVO, F.; GONZALO, C.

Daily and between-milking variations and repeatabilities in milk yield, somatic cell count, fat, and protein of dairy ewes. Small Ruminant Research. 24 (1997), 133-139

GALDVIN, D.; JENSEN, E.L.; HARDIE, A.R.

Variation in AM and PM fractions of yield in dairy cattle. 74 (1991) Suppl. 1. 268

GALTON, D. M. ; ADKINSON, R. W. ; SEEMAN, P. E. Jr.:

Comparison of Fossomatic somatic cell counter, Wisconsin Mastitis Test and California Mastitis Test.

J. Dairy Sci. 6 (1979) Suppl. 1, 120-121

GULYAS, L.; IVANCSICS, J.:

Zusammenhänge zwischen der somatischen Zellzahl und einigen eutermorphologischen Eigenschaften. Arch. Tierz., Dummerstorf 44 (2001) 1, 15-22

IMBAYARWO-CHIKOSI, E. V.; MAKUZA, S. M.; WOLLNY, C. B. A.; BANDA, J. W. Genetic and phenotypic parameters for individual cow somatic cell counts in Zimbabwean Holstein Friesian cattle. Arch. Tierz., Dummerstorf 44 (2001) 2, 129-137

KATONA, F.:

Measurement of the somatic cell count with a particle-counter method. (Guide of the use of Somati-02 instrument) Budapest-Gödöllö, 1991

LEJTÉNYI, GY; MÉSZÁROS, GY.:

The milk recording in the service of herd improvement, quality milk production and herd management in Hungary. ICAR-EAAP-FAO Round Table Workshop: Cattle Identification and Milk Recording in the Central and eastern European Countries, 1998.VIII.23. Warsaw, Poland

MILNE, J. R.:

Observations on the California Mastitis Test (CMT) reaction. II. Photomicrographic studies of somatic cells and their reaction with surface active agents. New Zealand J. Dairy-Sci. Tech. 12 (1977), 48-50

MILNE, J. R. ; LANGEN, H.:

Observations on the California Mastitis Test (CMT) reaction. I. The roles of deoxyribonucleic acid (DNA) and milk proteins in the reaction. New Zealand J. Dairy Sci. Tech. 12 (1977), 44-47

NAUMANN, I.; FAHR, R.-D.:

Untersuchungen zum Milchfluss aus Eutervierteln. Arch. Tierz., Dummerstorf 43 (2000) 5, 431-440

NAUMANN, I.; FAHR, R.-D.; LENGERKEN, G. v.:

Zusammenhang zwischen dem Gehalt an somatischen Zellen in der Milch und ausgewählten

Parametern der Milchflusskurve bei Kühen. Arch. Tierz., Dummerstorf 41 (1998) 3, 237-250

OKELLO-UMA, I; GIBSON, D. L.:

Screening tests for bovine mastitis. East-African Agricult. Forest. J. 1976, publ., 42. (1979), 127-131

PEDNEKAR, U. V. T ; SWARUP, D ; SRIVASTAVA, B. B.:

Evaluation of some indirect tests for detecting of sub-clinical mastitis. Indian J. Anim. Sci., 62. (1992), 1126-1130

SIMIANER, H.; SOLBU, H.; SCHAEFFER, L. R.

Estimated genetic correlations between disease and yield traits in dairy cattle. J. Dairy Sci., 74 (1991), 4358-4365

SMITH, J.W.; SCHULTZE, W.D.:

Variation in cell content of milk associated with time of sample collection. J. Dairy Sci., 50 (1967), 1083-1087

SÖLKNER, J.; MIESENBERGER, J.; WILLAM, A.; FUERST, CH.; BAUMUNG, R.:

Total merit indices in dual purpose cattle. Arch. Tierz., Dummerstorf 43 (2000) 6, 597-608

SYRSTAD, O.; RON, I.:

Daglig variasjon I celletall I mjolk. (Day-to-day variation in cell count in milk). Nord. Veterinaermed.,

SZÜCS, E.:

30 (1978), 192-198

Researches funding technological improvement in cattle breeding, Academic doctoral thesis, Gödöllö, 1998

VÁGI, J.:

Genetic methodological analyses using the grading system of somatic cell count in dairy cattle stocks.

XXVII. Óvár Scientific Symposium: New challenges and strategies in agricultural production.

Mosonmagyaróvár. 1996. Sept. 25. I. Vol. 180-184.p. 1998

WUFKA, M.; WILLEKE, H. 
Einfluss von Rasse und Laktationsnummer auf Eutermerkmale bei Milchkühen. Arch. Tierz., Dummerstorf 44 (2001) 5, 497-504

Received: 2001-08-27

Accepted: 2002-06-07

Authors address

ZSOMBOR BALTAY

Department of Cattle and Sheep Breeding

Szent István University, Gödöllő

H - 2103 Gödöllő

Hungary 